\title{
The Relationship between Home Environmental Conditions and the Occurrence of Acute Respiratory Infection (ARI) in Toddlers in Nagan Raya Regency
}

\author{
${ }^{1}$ Dian Fera, ${ }^{1}$ Susy Sriwahyuni \\ ${ }^{1}$ Public Health Faculty, Teuku Umar University, Indonesia \\ Coresponding author: Dian Fera, e-mail: dianfera@utu.ac.id \\ Co-author: SS: surysriwahyuni@utu.ac.id
}

Submitted: 19/03/2020 Revised: 06/04/2020 Accepted: 19/04/2020

Published online: $21 / 04 / 2020$

doi: https://doi.org/10.35308/j-kesmas.v7i1.1917 How to cite this article: Fera, D., \& Sriwahyuni, S. (2020). The relationship

between home environmental conditions and the occurrence of acute respiratory infection (ARI) in toddlers in Nagan Raya

Regency. J-Kesmas: Jurnal Fakultas Kesehatan Masyarakat (The Indonesian Journal of Public Health. 7(1): 38-43.

\begin{abstract}
Acute Respiratory Infection (ARI) is an infection that lasts up to 14 days. Most ARI are caused by infection, but can also be caused by inhalation of chemical and chemical substances. In 2018 the population was 3,885, with 342 children under five. The number of toddlers experiencing ARI is 218 toddlers. The purposes of this study were to determine the relationship of environmental conditions in the home with ARI in toddlers. This research uses analytic survey method with Cross Sectional approach. The study was conducted on August 20-September 5 2019, population 342 and sample of 77 peoples. The results showed there were a relationship among the house floor ( $\mathrm{P}$ value $0.018<\alpha 0.05, \mathrm{PR}=3.934)$, the room occupancy density $(\mathrm{P}$ value $0.006<\alpha 0.05, \mathrm{PR}=1.845)$, and the use of mosquito coils ( $\mathrm{P}$ value $0.001<\alpha 0.05, \mathrm{PR}=2.174)$ with ARI. The conclusion of the study was relationship among house floor, occupancy density factors and the use of mosquito coils with the incidence of ARI. It is expected that the health center can hold a health meeting with the community to protect the cleanliness of the floor of the house and not use mosquito repellent but replace it with a mosquito net when going to sleep and in one bedroom with an area of $8 \mathrm{~m} 2$ can only consist of 2 adults and 1 toddler, so make ventilation in every room in the house.
\end{abstract}

Keywords: house floor; residential density; mosquito coils; ARI

\section{Introduction}

Acute Respiratory Infections are often abbreviated as ARI. ARI is an infection that lasts up to 14 days. The 14 days limit is used for some diseases that can be classified in the ARI, and this process can last more than 14 days (Suryana, 2015). One of the causes of respiratory disease is a poor physical condition of the house. Respiratory disease can be transmitted due to inadequate ventilation. Respiratory disease and all diseases that spread through the air are easily transmitted to others if the house does not meet health requirements (Indonesian Ministry of Health, 2012)

Indoor air quality is air in a residential building that is inhabited by several people with different health conditions for at least one hour. Air quality is very influential on the health condition of its inhabitants. The risk of health problems can be compounded by the state of the home environment, chemicals, cleaning agents, and pollutants from outside the room. Air pollution in the home is said to be more dangerous because the source is close to humans who are exposed. In developing regions, indoor air pollution problems generally occur because of human activity in the room without the support of adequate ventilation or ventilation (Haris, et.al, 2012)

ARI is one of a global health problem until now. Acute respiratory infections (ARI) is one of the main causes of death in children under five years old (toddlers). In New York in 2014 based on WHO data the number of sufferers of ARI was 48,325 children and estimates in developing countries are around 3070 times higher than in developed countries and it is estimated that $20 \%$ of babies born in developing countries fail to reach the age of 5 years and 26-30\% of child deaths are caused by ARI. This is evident from the high morbidity and mortality rates causes by ARI. Deaths due to ARI in toddlers reached 12.4 
million in children aged $0-1$ years and as many as $80.3 \%$ of the deaths occurred in developing countries (Indonesian Ministry of Health, 2015). Nearly 6 million children under five die, $16 \%$ of this number is caused by pneumonia as the number 1 killer of toddlers in the world.

Data from the United Nations Agency for Children (UNICEF) shows that there are approximately $14 \%$ of the 147,000 toddlers in Indonesia die of pneumonia. Can be interpreted as many as 2-3 children under 5 years die every hour due to pneumonia. Pneumonia is the main cause of the death for toddlers of age in Indonesia (WHO, 2015). According to data reported by the Indonesian Ministry of Health in 2014 there were 657,490 people with ARI, West Java being the highest province with 197,654 cases (Indonesian Ministry of Health, 2015). The impact of ARI is that it can cause seizures, decreased consciousness, toddlers can experience malnutrition, experience hypoxia or lack of oxygen so that shortness of breath and respiratory failure that results in death (Suryana, 2015).

In Aceh province in 2012 there were 52,928 cases of patients suffering from ARI, with 2,395 cases being found and treated, North Aceh District was the region with the highest cases of 6,116 cases and Subussalam was the region with the lowest cases of 976 cases. Southwest Aceh District ranks $18^{\text {th }}$ from 23 Districts in Aceh (Aceh Health Office, 2013). In 2013 there were 427,258 cases of ARI, and the highest number of patients was in North Aceh District with 2,102 cases (Aceh Health Office, 2014). In 2014 the number of toddlers was 416,531 toddlers with 17,043 patients with ARI (Aceh Health Office, 2015). In 2015 the number of toddlers was 565,567 with 56,557 patients with ARI (Aceh Health Office, 2016).

Based on data of toddlers in Nagan Raya in 2017 there were 15,858 toddlers with number of case of ARI were 2,518 toddlers (16\%) (Nagan Raya District Health Office, 2017). In 2018 the number of toddlers were 15,858 toddlers, while in Nagan Raya District there were 3,108 toddlers suffering from ARI (19.6\%). Based on data from the Padang Rubek Health Center in 2016 the total number of toddlers were 555 . The number of toddlers who experienced ARI was 327 toddlers (58.9\%) (Padang Rubek Health Center, 2016). In 2017 the total number of toddlers were 719 toddlers. The number of toddlers experiencing ARI were 315 children (43.8\%) (Padang Rubek Health Center, 2017). Furthermore, in 2018 the total population will be 3,885 people, where the total number of toddlers will be 342 . The number of toddlers who experience ARI is 218 children (63.7\%) (Padang Rubek Health Center, 2018).

Based on interviews and observations with 6 mothers who have toddlers who experience ISPA, 2 mothers of toddlers with house conditions that pay attention to where the floor of his house is made of cement ie the floor of his house has broken so that there is land littered inside the house and the floor of the house is not plastered so the floor is easily broken. Furthermore, 2 mothers said that the number of occupants of a crowded room, namely 2 adults, 1 child and 1 toddler sleeping in one room, and one more mother whose room occupants are dense, lives on the side of the road, which causes a lot of dust to enter the house and does not have windows and ventilation in in the room so that there is no air exchange from inside the room where occupants of a crowded room require a lot of oxygen. Whereas 2 other mothers whose toddlers do not experience ISPA, stated that during sleep, mothers using mosquito nets do not use mosquito coils every day.

Based on the background above, the authors are interested in conducting research with the title "The Relationship of Environmental Conditions in the Home with the Occurrence of Acute Respiratory Infection (ARI) in Toddlers in the Work Area of the Padang Rubek Health Center in Kuala Pesisir SubDistrict, Nagan Raya Regency".

\section{Method}

The research was a quantitative study using analytic surveys with cross sectional approach to determine the relationship of environmental conditions at home with the incidence of acute respiratory infections (ARI) in toddlers in the working area of the Padang Rubek Health Center in Kuala Pesisir Sub-District, Nagan Raya Regency. The research was conducted on August 20 September 5 in 2019 in the Padang Rubek Health Center Work Area. The populations are mothers who have toddlers in the Working Area of Padang Rubek Health Center, as many as 342 respondents. The 
sampling technique used a random sample, that is the sample was selected based on respondents in the working area of the Padang Rubek Health Center when the study was conducted with 77 respondents.

\section{Results}

\section{Relationship between floor type with ARI occurrence in toddler}

Table 1. Relationship between house floor type and ARI occurrence in toddlers

\begin{tabular}{|c|c|c|c|c|c|c|c|c|}
\hline \multirow{3}{*}{ House Floor Type } & \multicolumn{4}{|c|}{ ARI in Toddlers } & \multirow{2}{*}{\multicolumn{2}{|c|}{ Total }} & \multirow{3}{*}{$P_{\text {Value }}$} & PP \\
\hline & \multicolumn{2}{|c|}{ Sick } & \multicolumn{2}{|c|}{ Not Sick } & & & & \\
\hline & $\mathrm{f}$ & $\%$ & $\mathrm{f}$ & $\%$ & $\mathrm{f}$ & $\%$ & & CI 95\% \\
\hline Qualify & 14 & 87.5 & 2 & 12.5 & 16 & 100 & 0.018 & 3,934 \\
\hline Not Qualify & 31 & 50.8 & 30 & 49.2 & 61 & 100 & & $(1,050-14,747)$ \\
\hline
\end{tabular}

Based on Table 1 shows that of the 16 floor types fulfilling the requirements of 14 respondents $(87.5 \%)$ whose toddlers require ISPA. Furthermore, of the 61 types of floors that did not meet the requirements of 31 respondents $(50.8 \%)$ whose toddlers needed ISPA. Chi square test results with
$\mathrm{P}_{\text {Value }}=0.018$, so that it can be estimated related between the type of house floor with the ARI in Toddlers $\left(\mathrm{P}_{\text {Value }}=0.018<\alpha=0.05\right)$, and based on the $\mathrm{RP}$ value that can be displayed according to the type of shoes needed by 3,3934 times with ARI events in toddlers.

\section{Relationship between room occupancy density with ARI occurrence in toddler}

Table 2. Relationship between room occupancy density and ARI occurrence in toddlers

\begin{tabular}{lcccccccc}
\hline \multirow{2}{*}{$\begin{array}{l}\text { Room Occupancy } \\
\text { Density }\end{array}$} & \multicolumn{4}{c}{ ARI in Toddlers } & \multicolumn{2}{c}{ Total } & \multirow{2}{*}{ Pvalue } & PR \\
\cline { 2 - 6 } & f & $\%$ & f & $\%$ & f & $\%$ & & CI 95\% \\
\hline Dense & 14 & 40.0 & 21 & 26.2 & 35 & 100 & 0.006 & 1,845 \\
\hline Not Dense & 31 & 73.8 & 11 & 60.0 & 42 & 100 & & $(1,184-2,876)$ \\
\hline
\end{tabular}

Based on table 2 shows of 35 respondents whose room category is dense as many as 14 respondents $(40.0 \%)$ who increased ISPA, while of 42 respondents in the room category are not solid as many as 31 respondents $(73.8 \%)$ who use ISPA. Chi square test results with $\mathrm{P}_{\text {value }}=0.006$, so it can be explained related to the significance of the concentration of occupancy with ARI in Toddlers $\left(\mathrm{P}_{\text {value }}=0.006<\alpha=0.05\right)$. From the homework score, can we conclude that this has a strong chance of 1,845 times for children to spend ISPA on toddlers.

\section{Relationship between Mosquito Coils with ARI occurrence in toddler}

Table 3. Relationship between mosquito coils with ARI occurrence in toddler

\begin{tabular}{|c|c|c|c|c|c|c|c|c|}
\hline \multirow{3}{*}{ Mosquito Coils } & \multicolumn{4}{|c|}{ ARI in Toddlers } & \multirow{2}{*}{\multicolumn{2}{|c|}{ Total }} & \multirow{3}{*}{$P_{\text {Value }}$} & \multirow{3}{*}{$\begin{array}{c}\text { PR } \\
\text { CI 95\% }\end{array}$} \\
\hline & \multicolumn{2}{|c|}{ Sick } & \multicolumn{2}{|c|}{ Not Sick } & & & & \\
\hline & $\mathrm{f}$ & $\%$ & $\mathrm{~F}$ & $\%$ & $\mathrm{f}$ & $\%$ & & \\
\hline Use & 12 & 35.3 & 22 & 64.7 & 34 & 100 & 0.001 & 2,174 \\
\hline Do not use & 33 & 76.7 & 10 & 23.3 & 43 & 100 & & $(1,340-3,528)$ \\
\hline
\end{tabular}

Based on table 3 it is known that of 34 respondents who used mosquito coils as many as 34 respondents $(35.3 \%)$ who experienced ARI, while of 43 respondents who did not use mosquito coils as many as 33 respondents (76.7\%) who experienced ARI.
Chi square test results with $\mathrm{P}_{\text {value }}=0.001$, so described there is a significant relationship between use of mosquito coils with ARI in Toddlers $\left(\mathrm{P}_{\text {value }}=\right.$ $0.001<\alpha=0.05$ ). From the PR value it can be concluded that using mosquito coils has a strong 
chance that is 2,174 times to make a toddler to experience ARI in a toddlers.

\section{Discussion}

\section{Relationship between house floor type and ARI occurrence in toddler}

Chi square test results obtained of $\mathrm{P}_{\text {Value }}=$ 0.018 , so that it can be estimated related between the type of house floor with the ARI in Toddlers ( $\mathrm{P}_{\text {value }}=$ $0.018<\alpha=0.05$ ), and based on the RP value that can be displayed according to the type of shoes needed by 3,3934 times with ARI events in toddlers. The results of this study are same with Supit et al. (2016) which states that there is a relationship between the house floor and the incidence of ARI in toddlers in Talawaan Atas and Kima Bajo villages, Wori subdistrict, North Minahasa regency $(p=0,000 ; r=$ 0.736 ,). Another study that supports this research is Yuslinda (2017) where there is a relationship between the type of floor with the incidence of ARI in the Community of Ranomeeto, Ranomeeto District with $\rho$ Value $=0.016$. Likewise with Putri (2019), a relationship was found between the floor of the house and the incidence of ARI in infants in Ciwandan District, Ciligon City July-August 2016 with $\mathrm{p}$ Value $=0.001$.

Based on these results, the researchers are of the opinion that the respondent's home floor has a relationship with the incidence of ARI. Based on observations made by researchers in the field the floor owned by respondents mostly in the form of cement floor that is not plaster and kitchen floor from the ground, so that during the dry season there is a lot of dust. The floor is made of cement on average has been damaged and potholes, this makes the floor becomes dusty and moist. A good floor must be waterproof, not humid, the floor material is easy to clean and in a dry condition and does not produce dust, but in this study at the time of the investigation many respondents' houses were not good enough, where many of the floors were moist/not dry. Communities in the working area of the Padang Rubek Community Health Center are people who have a modest income so that all of their income is only sufficient to meet the needs of life and schooling of children, so that their lives are simple. Their lives are simple, so they feel that damaged floors and kitchen floors that are only from the ground cannot cause health problems for them and their family members.

Whereas respondents who have decent house flooring and their respondents do not experience ARI because clean house floor is free from dust, thus making the respondent avoid ARI. Furthermore, respondents who have unfit floors and do not experience ARI because of the ISPA incident they experienced were caused by other variables, namely the density of room occupancy and the use of mosquito coils.

House floor Components that must be filled with a healthy home have a waterproof floor and are not damp. Ground floor type has a role in the process of ARI, through indoor humidity. Ground floor tends to cause moisture, in the summer the floor becomes dry so that it can cause dust which is dangerous for its inhabitants (Hera, 2013).

\section{Relationship between occupancy density and acute respiratory infection}

Chi square test results obtained of $\mathrm{P}_{\text {value }}=$ 0.006 , so it can be explained related to the significance of the concentration of occupancy with ARI in Toddlers $\left(\mathrm{P}_{\text {value }}=0.006<\alpha=0.05\right)$. From the homework score, can we conclude that this has a strong chance of 1,845 times for children to spend ARI on toddlers. The results of this study are in line with Wahyuningsih et al. (2017) which states that there is a relationship between Occupancy Density and the Occurrence of ARI in infants in the coastal area of Kore Village, Sanggar District, Bima Regency in 2014 with a P value $=0.000$. Likewise with research conducted by Yusuf, Sudayasa, and Nurtamin (2016) which states that there is a relationship between occupancy density and the incidence of ARI in the coastal communities of Lapulu Village, Abeli District with $\alpha=0.05$ and $\mathrm{P}$ value $=0,000$. This research is also supported by Agungnisa (2019) which states that the density of toddlers' room occupancy $(p=0.004)$ influences the incidence of ARI in under five in the village of East Kalanget.

Based on observations by researchers in the field it was found that respondents who have dwelling in dense rooms and experience ARI due to the dense room situation so that the air feels less and 
a bit congested, besides that the distribution of air is also insufficient in the room, this researchers see where the size of the room is not widely occupied by 2 adults and 1 toddler and 1 elementary school child. In addition there are also occupied by 5 people where 2 adults 1 toddler, 1 child aged 5 years and one elementary school child, this makes the room feel crowded and crowded. Furthermore respondents who have less crowded room occupancy density experience less ARI events because the air in the room or house can be felt comfortably by the occupants of the house, in the mother's room sleeping with her husband, toddlers and children aged 7 years. Whereas respondents whose density of room occupancy is not congested and have ARI due to factors that cause toddlers experiencing ARI are other factors namely the presence of dust at home, this researcher knows based on the explanation of respondents that based on the results of examinations at the public health center the child has ARI due to inhalation of existing dust at home.

The density of housing in the home according to the Decree of the Minister of Health of the Republic of Indonesia No.829/Menkes/SK/VII /1999 regarding home health requirements, the density of residential bedrooms is a minimum of $8 \mathrm{~m} 2$ and is not recommended for use by more than 2 people except children under 5 years. Based on these criteria is expected to prevent the transmission of diseases such as ARI and launch activities. Dense living conditions can increase pollution factors in existing homes.

\section{The relationship of the use of mosquito coils with ARI}

Chi square test results obtained of $\mathrm{P}_{\text {value }}=$ 0.001 , so described there is a significant relationship between the use of mosquito coils with ARI in Toddlers $\left(\mathrm{P}_{\text {value }}=0.001<\alpha=0.05\right)$. From the PR value it can be concluded that using mosquito coils has a strong chance that is 2,174 times to make a toddler to experience ARI in a Toddlers. The results of this study are equal with research by Trisnawati et al. (2013) which states there is a relationship between the use of mosquito coils with ARI events in infants in the work area of Rembang Public Health Center in Purbalingga Regency in 2012 with a value of $p=$ $0.017(<0.05)$ and an OR value of 1,325 .
There are other studies that also support the results of previous studies, namely Sofia (2017) which shows a relationship between the habit of using mosquito coils with ARI in toddlers with a value of $p=0.003(p<0.05)$. in the working area of the Health Center of Want Jaya, Aceh Besar district. Furthermore, research conducted by Saleh (2017) which shows the relationship of pollutants in the home is the use of mosquito coils with a value $(\mathrm{p}=$ 0.000) in Toddlers in Mariso District, Makassar City.

Based on observations in the field the researchers found that respondents who used mosquito coils in their homes experienced ISPA events because mosquito coils smoke is not good for health can damage the lungs and can cause various diseases such as ARI, respondents said using mosquito coils to repel mosquitoes so as to avoid dengue, and while sleeping they are not bitten by mosquitoes. In addition, respondents felt the use of mosquito coils was cheaper than buying mosquito nets.

Furthermore the respondents also stated they did not use mosquito nets because using mosquito nets for too long had to tie a rope in the mosquito nets and they also said when using the lamp felt it was stuffy while the use of mosquito coils was more practical to just burn it. Whereas respondents who did not use mosquito coils at their home had fewer ARI events because the house was clean from burning mosquito coils so that it did not damage the lungs and avoid ARI. Respondents use mosquito nets while sleeping to avoid mosquito bites.

\section{Conclusion}

1. There is a significant relationship between house floor factor with ARI events in toddlers and home floor factors can increase the incidence of ARI in toddlers

2. There is a significant relationship between room occupancy density factors with ARI events in toddlers and room occupancy density factors can increase the incidence of ARI in toddlers.

3. There is a significant relationship between mosquito coils factors and the incidence of ARI in toddlers and mosquito coils factors can increase the incidence of ARI in toddlers. 


\section{Acknowledgement}

Thanks to the Padang Rubek Health Center for giving permission and contributing data in this study.

\section{Author Contribution and Competing Interest}

All authors contribute to the process of the research. The author assures that there is no conflict of interests in the activities and preparation of this report.

\section{Publisher's Note}

J-Kesmas: Jurnal Fakultas Kesehatan Masyarakat (Indonesia Journal of Public Health) remains neutral with regard to jurisdictional claims in published institutional affiliation.

\section{References}

Aceh Health Office (2013) Profil kesehatan Aceh. Aceh.

Aceh Health Office (2014) Profil kesehatan Aceh. Aceh.

Aceh Health Office (2015) Profil kesehatan Aceh. Aceh.

Aceh Health Office (2016) Profil kesehatan Aceh. Aceh.

Agungnisa, A. (2019) Physical Sanitation of the House that Influence the Incidence of ARI in Children under Five in Kalianget Timur Village. Jurnal Kesehatan Lingkungan, 11(1), $1-9$.

Haris, A., Ikhsan, M., \& Rogayah, R. (2012) Asap rokok sebagai bahan pencemar dalam ruangan. CDK-189, 39(1): 17-24

Indonesian Ministry of Health (2012) Pedoman pengendalian penyakit infeksi saluran pernapasan. Jakarta.

Indonesian Ministry of Health (2015) Profil kesehatan Indonesia. Jakarta.

Nagan Raya District Health Office (2017) Profil kesehatan Nagan Raya tahun 2017. Nagan Raya.

Padang Rubek Health Center (2016) Data ISPA di wilayah kerja Puskesmas Padang Rubek.

Padang Rubek Health Center (2017) Data ISPA di wilayah kerja Puskesmas Padang Rubek.

Padang Rubek Health Center (2018) Data ISPA di wilayah kerja Puskesmas Padang Rubek.
Putri (2019) Pengaruh lingkungan fisik rumah terhadap kejadian ispa pada balita Di Kecamatan Ciwanda Kota Cilegon Periode Juli - Agustus 2016. Tarumanagara Medic. J., 1(2): 389-394.

Saleh (2017) Hubungan ventilasi, lantai, dinding, dan atap dengan kejadian penyakit pneumonia pada balita di wilayah kerja Puskesmas Pekayon Jaya Kota Bekasi. J. Kesehatan Masyarakat (eJournal), 4(5): 187-195

Sofia (2017). Faktor risiko lingkungan dengan kejadian ispa pada balita di wilayah kerja Puskesmas Ingin Jaya Kabupaten Aceh Besar. J. Action, 2(1): 43-50.

Supit, A. F., Joseph, W. B. S., \& Kaunang, W. P. (2016) Hubungan antara lingkungan fisik rumah dengan kejadian penyakit infeksi saluran pernapasan akut pada balita di Desa Talawaan Atas dan Desa Kima Bajo Kecamatan Wori Kabupaten Minahasa Utara. Pharmacon: Jurnal Ilmiah Farmasi UNSRAT, 5(2): 259-265.

Suryana (2015) Berbagai masalah kesehatan anak dan balita. Jakarta: Khilms.

Trisnawati, Trisnawati, Y., \& Juwarni, J. (2013) Hubungan perilaku merokok orang tua dengan kejadian ISPA pada balita di wilayah kerja Puskemas Rembang Kabupaten Purbalingga. Jurnal Ilmiah Kesehatan Masyarakat, 6(1): $35-42$.

Wahyuningsih, S., Raodhah, S., \& Basri, S. (2017) Infeksi saluran pernafasan akut (ISPA) pada Balita di wilayah pesisir Desa Kore Kecamatan Sanggar Kabupaten Bima. HIGIENE: J. Kesehatan Lingkungan, 3(2): 97-105.

Yuslinda (2017) Hubungan kondisi lingkungan dalam rumah dengan kejadian penyakit infeksi saluranpernafasan akut (ispa) pada masyarakat di Kelurahan Ranomeeto Kecamatan Ranomeeto Tahun 2017. Jimkesmas, 2(6): 1-9.

Yusuf, M., Sudayasa, I.P., \& Nurtamin, T. (2016) Hubungan lingkungan rumah dengan kejadian infeksi saluran pernapasan akut (ISPA) pada masyarakat pesisir Kelurahan Lapulu Kecamatan Abeli Tahun 2014. Medula: J. Ilmiah Fakultas Kedokteran Universitas Halu Oleo, 3(2): 239-248. 